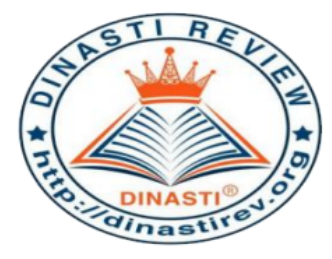

+62 878-9658-6407

087896586407

https://dinastirev.org/JIMT editor@dinastirev.org

\title{
PENGARUH LINGKUNGAN KELUARGA DAN EFIKASI DIRI TERHADAP MOTIVASI BERWIRAUSAHA SERTA DAMPAKNYA TERHADAP INTENSI BERWIRAUSAHA MAHASISWA FAKULTAS KEGURUAN DAN ILMU PENDIDIKAN (FKIP) UNIVERSITAS JAMBI
}

\author{
Suratno' $^{1}$, Farida Kohar ${ }^{2)}$, Ali Idrus ${ }^{3)}$, Suci Pratiwi ${ }^{4)}$ \\ 1) Universitas Jambi, Kota Jambi, Indonesia \\ 2) Universitas Jambi, Kota Jambi, Indonesia \\ 3) Universitas Jambi, Kota Jambi, Indonesia \\ ${ }^{4}$ ) Universitas Jambi, Kota Jambi, Indonesia
}

\begin{tabular}{|c|c|}
\hline $\begin{array}{l}\text { ARTICLE INFORMATION } \\
\text { Received: } 12 \text { Maret } 2020 \\
\text { Revised: } 17 \text { Maret } 2020 \\
\text { Issued: } 23 \text { Maret } 2020\end{array}$ & $\begin{array}{l}\text { Abstrak: Tingginya angka pengangguran telah menuntut berbagai } \\
\text { pihak berupaya untuk menumbuhkan jiwa kewirausahaan kepada } \\
\text { masyarakat. Salah satunya yaitu melalui pendidikan kewirausahaan } \\
\text { yang diterapkan di sekolah maupun perguruan tinggi. Hal ini } \\
\text { dilakukan untuk menciptakan wirausaha-wirausaha muda yang } \\
\text { berstatus sarjana yang dapat membantu pemerintah dalam } \\
\text { mengurangi angka pengangguran. Tujuan Penelitian: 1) Untuk } \\
\text { mengetahui pengaruh lingkungan keluarga terhadap motivasi } \\
\text { berwirausaha; 2) Untuk mengetahui pengaruh motivasi berwirausaha } \\
\text { terhadap intensi berwirausaha; 3) Untuk mengetahui pengaruh } \\
\text { lingkungan keluarga terhadap intensi berwirausaha; 4) Untuk } \\
\text { mengetahui pengaruh efikasi diri terhadap intensi berwirausaha; 5) } \\
\text { Untuk mengetahui pengaruh motivasi berwirausaha terhadap intensi } \\
\text { berwirausaha; 6) Untuk mengetahui pengaruh lingkungan keluarga } \\
\text { terhadap intensi berwirausaha melalui motivasi berwirausaha; dan 7) } \\
\text { Untuk mengetahui pengaruh efikasi diri terhadap intensi } \\
\text { berwirausaha melalui motivasi berwirausaha. Berdasarkan tujuan } \\
\text { penelitian, penelitian ini dikategorikan sebagai penelitian penjelas } \\
\text { (eksplanatory research). Teknis analisis yang digunakan dalam } \\
\text { penelitian ini adalah analisis jalur (path analisys) yang bantu } \\
\text { menggunakan alat SPSS 21.0. for windows yang digunakan dalam } \\
\text { pengembangan model dan pengujian hipotesis. Hasil analisis data } \\
\text { yang diperoleh menjelaskan bahwa: 1) terdapat pengaruh lingkungan } \\
\text { keluarga terhadap motivasi berwirausaha sebesar 0,826; } 2 \text { ) terdapat } \\
\text { pengaruh efikasi diri terhadap motivasi berwirausaha sebesar 0,645; } \\
\text { 3) terdapat pengaruh lingkungan keluarga terhadap intensi } \\
\text { berwirausaha sebesar 0,823; 4) terdapat pengaruh efikasi diri } \\
\text { terhadap intensi berwirausaha sebesar 0,660; 5) terdapat pengaruh } \\
\text { motivasi berwirausaha terhadap intensi berwirausaha sebesar 0,871; } \\
\text { 6) terdapat pengaruh tidak langsung lingkungan keluarga terhadap } \\
\text { intensi berwirausaha melalui motivasi berwirausaha dengan koefisien } \\
\text { mediasi sebesar 0,719446; dan 7) terdapat pengaruh tidak langsung } \\
\text { efikasi diri terhadap intensi berwirausaha melalui motivasi } \\
\text { berwirausaha dengan koefisien mediasi sebesar 0,561795. } \\
\text { Kata Kunci: Lingkungan Keluarga, Efikasi Diri, Motivasi } \\
\text { Berwirausaha, dan Intensi Berwirausaha. }\end{array}$ \\
\hline
\end{tabular}

\section{PENDAHULUAN}

Pengangguran merupakan masalah yang sangat kompleks karena mempengaruhi sekaligus dipengaruhi oleh beberapa faktor yang saling berinteraksi mengikuti pola yang 
tidak selalu mudah dipahami. Tingginya angka pengangguran akhir-akhir ini dikarenakan tidak sebandingnya jumlah lapangan kerja yang tersedia dengan pencari kerja, diikuti dengan jumlah lulusan yang terus bertambah tiap tahunnya, akibatnya jumlah pengangguran terus meningkat. Menurut Badan Pusat Statistik (BPS) pada Agustus 2017 lalu, BPS mengungkapkan bahwa jumlah pengangguran naik menjadi 7,04 juta jiwa, dari yang sebelumnya hanya 7,03 juta jiwa di bulan Agustus 2016. Peningkatan ini diiringi dengan penurunan angka Tingkat Pengangguran Terbuka atau TPT, dari 5,61\% menjadi 5,50\%. TPT sendiri merupakan persentase jumlah pengangguran yang termasuk dalam penduduk usia kerja terhadap jumlah angkatan kerja. Untuk tahun 2018, BPS melaporkan bahwa jumlah pengangguran di Indonesia berkurang sebanyak 140.000 jiwa. Persentase TPT yang juga turun ke angka 5,13\% dari 5,33\% pada Februari 2017. Total jumlah angkatan kerja tahun 2018 naik sebanyak 2,39 juta dari Februari 2017 menjadi 133,94 juta jiwa, dengan jumlah pengangguran sebanyak 6,87 juta dan yang bekerja sebanyak 127,07 juta jiwa (https://glints.com/id/lowongan/fakta-pengangguran-indonesia/).Tingginya angka pengangguran ini, telah menuntut berbagai pihak termasuk pemerintah berupaya untuk menumbuhkan jiwa kewirausahaan kepada masyarakat,

Di Universitas Jambi sendiri, program pendidikan dan pembelajaran kewirausahaan telah diberikan kepada mahasiswanya sejak lama, dan dijadikan sebagai matakuliah yang wajib harus diikuti mahasiswa. Hal ini dilakukan sebagai salah satu upaya untuk mendorong intensi berwirausaha pada diri mahasiswa. Namun sayangnya upaya tersebut belumlah begitu membuahkan hasil, hal ini dikarenakan para lulusan perguruan tinggi tidak mau untuk langsung terjun sebagai wirausahawan, dan cenderung lebih memilih untuk menjadi pegawai atau karyawan setelah lulus kuliah. Profesi sebagai pegawai atau karyawan dinilai lebih praktis dan menyenangkan daripada berwirausaha. Untuk mengetahui intensi berwirausaha pada mahasiswa, penulis melakukan survey awal. Survey awal ini dilakukan pada mahasiswa semester lima pada Program Studi Pendidikan Ekonomi, Fakultas Keguruan dan Ilmu Pendidikan, Universitas Jambi TA. 2018/2019 dengan tujuan untuk mengetahui intensi mahasiswa untuk menjadi seorang wirausaha setelah lulus nanti. Adapun hasil pra survey yang dilakukan disajikan dalam Gambar 1. berikut.

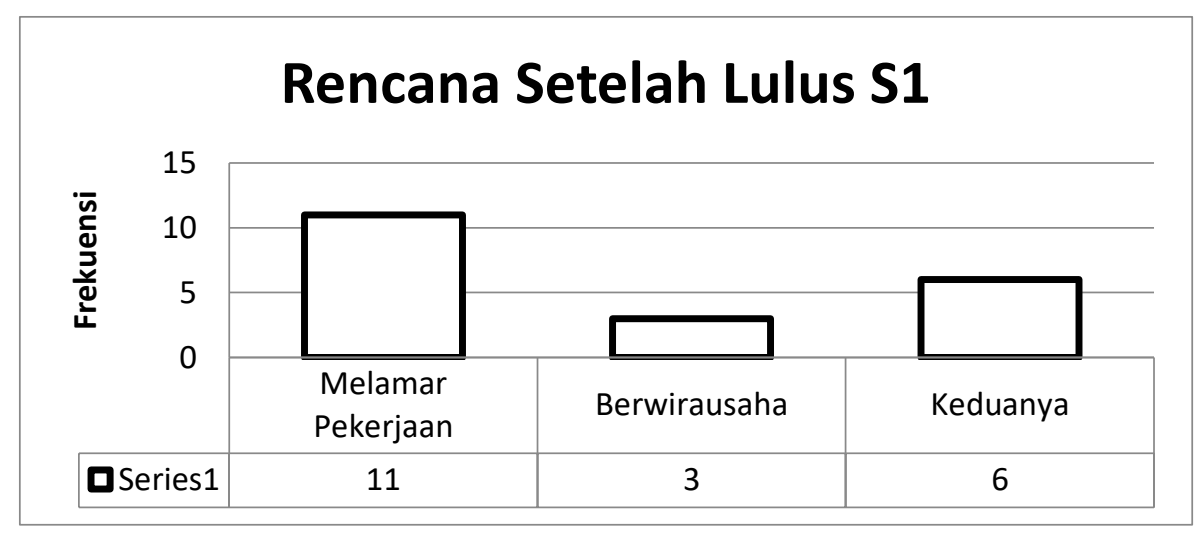

Gambar 1. Rencana Setelah Lulus S1

Sumber: Pra Survey Penelitian, 2019.

Dari hasil pra survey yang di ajukan kepada 20 mahasiswa Program Studi Pendidikan Ekonomi, Fakultas Keguruan dan Ilmu Pendidikan, Universitas Jambi TA. 2018/2019 yang telah menempuh mata kuliah kewirausahaan, diketahui bahwa sebagian besar mahasiswa menjawab akan melamar pekerjaan, dan sangat sedikit sekali yang akan berwirausaha yaitu hanya 3 orang dari 20 mahasiswa yang di survey. 
Menurut Suryana (2013) menyebutkan bahwa faktor yang dapat mendorong seseorang berwirausaha dapat dipengaruhi oleh faktor internal dan faktor eksternal. Faktor internal adalah faktor yang berasal dari dalam diri seseorang dapat berupa sifat-sifat personal, sikap, keyakinan, kemauan dan kemampuan individu yang dapat memberi kekuatan individu untuk berwirausaha. Sedangkan faktor eksternal adalah faktor yang berasal dari luar diri seseorang yang dapat berupa unsur dari lingkungan sekitar seperti lingkungan keluarga, lingkungan dunia usaha, lingkungan fisik, lingkungan sosial ekonomi. Adapun lingkungan sosial ekonomi yang dimaksud termasuk juga kedalam lingkungan sekolah, lingkungan teman sejawat, dan lingkungan masyarakat secara umum.

Selain lingkungan keluarga, adapun faktor lain yang dapat mempengaruhi motivasi dan intensi berwirausaha yaitu efikasi diri. Hal ini dikemukan oleh Bandura dalam Puspitaningsih, F (2014) yang mengemukakan bahwa efikasi diri mempengaruhi bentuk tindakan yang akan mereka pilih untuk dilakukan, sebanyak apa usaha yang akan mereka berikan ke dalam aktivitas ini, selama apa mereka akan bertahan menghadapi rintangan dan kegagalan, serta ketangguhan mereka mengikuti adanya kemunduran". Efikasi diri dapat mempengaruhi seseorang terhadap sesuatu hal yang dipercaya. Membuka sebuah usaha memerlukan kepercayaan terhadap kemampuan diri sendiri bahwa usahanya akan berhasil, hal inilah yang akan memotivasi seseorang untuk berani memulai suatu usaha. Apabila seseorang tidak percaya akan kemampuan yang dimiliki, kecil kemungkinan orang tersebut akan terdorong untuk berwirausaha. Fenomena inilah yang kebanyakan terjadi saat ini, berdasarkan hasil pengamatan yang penulis lakukan, rendahnya motivasi berwirausaha pada mahasiswa saat ini akibat dari kurangnya kepercayaan diri mahasiswa untuk berwirausaha dengan bermacam alasan, seperti adanya rasa takut bahwa usahanya akan rugi, berwirausaha itu sulit, membutuhkan modal besar, memiliki resiko yang besar dan lain sebagainya.

Tujuan Penelitian didalam penelitian ini adalah Untuk mengetahui pengaruh lingkungan keluarga terhadap motivasi berwirausaha, Untuk mengetahui pengaruh motivasi berwirausaha terhadap intensi berwirausaha, Untuk mengetahui pengaruh lingkungan keluarga terhadap intensi berwirausaha, Untuk mengetahui pengaruh efikasi diri terhadap intensi berwirausaha, Untuk mengetahui pengaruh motivasi berwirausaha terhadap intensi berwirausaha, Untuk mengetahui pengaruh lingkungan keluarga terhadap intensi berwirausaha melalui motivasi berwirausaha dan untuk mengetahui pengaruh efikasi diri terhadap intensi berwirausaha melalui motivasi berwirausaha. Defenisi Konseptual dalam penelitian ini adalah Intensi Berwirausaha, Intensi berwirausaha adalah niat yang dimiliki individu untuk menciptakan lapangan kerja baru yaitu dengan cara mengubah sesuatu yang tak bernilai atau bernilai rendah menjadi sesuatu yang bernilai. Motivasi Berwirausaha, motivasi berwirausaha merupakan suatu dorongan yang timbul dari diri seseorang untuk mengambil atau melakukan kegiatan yang berkaitan dengan bidang kewirausahaan. Lingkungan Keluarga, lingkungan keluarga merupakan lingkungan pendidikan yang utama dan pertama yang dialami anak dalam berinteraksi dengan anggota keluarga, baik interaksi secara langsung maupun tidak langsung. Efikasi Diri, efikasi diri merupakan rasa percaya diri yang dimiliki seseorang bahwa dirinya mampu untuk menyelesaikan tugas dengan efektif dan efisien sehingga tugas tersebut menghasilkan dampak yang diharapkan. Efikasi diri yang merujuk pada keyakinan diri sendiri mampu melakukan sesuatu yang diinginkannya, dapat dijadikan prediksi tingkah laku. Dan Defenisi Operasional dalam penelitian ini adalah 1) Intensi Berwirausaha, 2) Motivasi Berwirausaha 3) Lingkungan Keluarga 4) Efikasi Diri.

KAJIAN PUSTAKA

\section{A. Intensi Berwirausaha}


1. Pengertian Intensi Berwirausaha

Intensi berwirausaha adalah niat yang dimiliki individu untuk menciptakan lapangan kerja baru yaitu dengan cara mengubah sesuatu yang tak bernilai atau bernilai rendah menjadi sesuatu yang bernilai.

2. Faktor yang Mempengaruhi Intensi Berwirausaha

Menurut Ajzen (2005) adapun faktor-faktor yang mempengaruhi perilaku berdasarkan Theory of Planned Behaviour dan Faktor-faktor yang mempengaruhi intensi dapat dipahami dalam penjelasan berikut ini:

a. Faktor Internal
a) Attitude toward Behaviour (Sikap Terhadap Perilaku)
b) Norma Subjektif
c) Kontrol Perilaku

b. Faktor Eksternal

a) Latar Belakang Individual

b) Latar Belakang Sosial

c) Latar Belakang Informasi

3. Indikator Intensi Berwirausaha

Menurut Isabella (2010) adapun indikator dari intensi berwirausaha adalah sebagai berikut :
a. Pendidikan
b. Pengalaman Kerja
c. Keluarga

\section{B. Motivasi Berwirausaha}

1. Pengertian Motivasi Berwirausaha

Gilad dan Levine dalam Ahmad (2010) menawarkan dua penjelasan yang berhubungan dengan motivasi untuk menjadi wirausaha, yaitu:
a. Push theory,
b. Pull theory,

2. Teori Motivasi

Adapun beberapa teori motivasi tersebut adalah Teori Dorongan, teori motivasi Maslow, teori dua faktor, teori kebutuhan McClelland, teori dorongan dan tarikan (Push Theory dan Pull Theory)

3. Faktor-Faktor Yang Mempengaruhi Motivasi Berwirausaha

Banyak faktor yang dapat mendorong seseorang untuk membuka usaha atau menjadi seorang wirausaha, menurut Alma (2018) adapun faktor yang dapat mendorong seseorang untuk berwirausaha dapat dipengaruhi oleh dorongan dari keluarga, keadaan lapangan kerja dan sumber daya yang tersedia. Indikator Motivasi Berwirausaha

\section{Lingkungan Keluarga}

1. Pengertian Lingkungan Keluarga

Keluarga dalam ilmu sosiologi menjadi salah satu yang mendapat perhatian khusus. Keluarga dianggap penting sebagai bagian dari masyarakat secara umum. Karena keluarga terbentuk dari individu-individu yang pada akhirnya akan membentuk masyarakat (Latif, A, 2011).

2. Lingkungan Keluarga Sebagai Unit terkecil Dari Masyarakat 
Keluarga sebagai unit sosial terkecil dalam masyarakat merupakan lingkungan budaya pertama dan utama dalam rangka membentuk norma dan mengembangkan berbagai kebiasaan, perilaku dan sikap yang dianggap penting bagi kehidupan pribadi, keluarga dan lingkungan masyarakat.

3. Peranan Keluarga

Pada sebuah kajian, para orang dewasa lebih berpegang teguh pada keyakinan mereka akan benar atau salah ketika dihadapi dengan sebuah dilema moral meminta para orang tua untuk dapat membimbing anak-anak mereka secara serius ketika menemukan suatu sikap penyimpangan moral. Orang tua yang sadar akan hal tersebut akan menyikapinya dengan berbeda ketika anak-anak mereka ketahuan melakukan suatu tindakan yang mengecewakan ataupun menyakiti orang lain dibandingkan dengan orang tua baik. Orang tua lebih peduli untuk meminta anaknya menyesali perbuatannya, menunjukkan kekecewaan atas hal tersebut, mencari tahu apa yang menjadi kesalahan dari apa yang telah diperbuatannya, memunculkan sikap tanggung jawab, serta meminta mereka untuk meminta maaf dan memperbaiki kesalahannya.

4. Fungsi Keluarga

Secara sosiologis, Sudjana, D (2012) mengemukakan tujuh macam fungsi keluarga, yaitu 1) fungsi biologis, 2) fungsi edukatif, 3) fungsi relegius, 4) fungsi protektif, 5) fungsi sosialisasi, 6) fungsi rekreatif, 7) fungsi ekonimis.

5. Indikator Lingkungan Keluarga

Slameto (2010) mengungkapakan indikator lingkungan keluarga sebagai berikut:

a. Cara orang tua mendidik.

b. Relasi antar anggota keluarga.

c. Suasana rumah.

d. Keadaan ekonomi keluarga.

e. Pengertian orang tua.

f. Latar belakang kebudayaan.

\section{Efikasi Diri (Self Efficacy)}

1. Pengertian Efikasi Diri

Gibson, James L., John M. Ivancevich, James H. Donnelly, Jr. and Robert Konopaske dalam Wibowo (2013) mengemukakan bahwa efikasi diri adalah keyakinan bahwa seseorang dapat mengerjakan dengan cukup dalam suatu situasi tertentu. Efikasi diri mempunyai tiga dimensi terdiri dari magnitude, strength, generality. Magnitude merupakan tingkat kesulitan pendirian berdasarkan besaran sebagai kuat atau lemah. Sedangkan generality menunjukkan tingkatan dimana harapan digeneralisir di semua situasi.

2. Proses dan Dampak Efikasi Diri

Menurut Luthan (2006) proses efikasi diri mempengarui fungsi manusia bukan hanya secara langsung, tetapi juga mempunyai pengaruh tidak langsung terhadap faktor lain. Secara langsung, proses efikasi diri dimulai sebelun individu memilih pilihan mereka dan mengawaliusaha meraka.

3. Sumber Efikasi Diri

Lebih lanjut Luthan (2006) menjelaskan bahwa menurut kepentingannya, sumber utama efikasi diri adalah sebagai berikut:

a. Pengalaman penguasaan (mastery experience) atau pencapaian kinerja

b. Pengalaman pribadi atau pemodelan

c. Persuasi social 
d. Peningkatan fisik dan psikologis

4. Cara Meningkatkan Efikasi Diri

Bandura dalam Robbins dan Judge (2015), mengusulkan ada empat cara untuk meningkatkan efikasi diri yaitu: 1) Kemahiran dalam melaksanakan; 2) Pemodelan yang dilakukan; 3) Bujukan secara lisan; dan 4) Stimulasi.

5. Komponen Self Efficacy

Menurut Bandura (2006) perbedaan self efficacy pada setiap individu terletak pada tiga komponen adalah Magnitude, Strength, dan Generality.

\section{E. Kerangka Berpikir}

Adapun paradigma dari kerangka pemikiran dari penelitian dapat digambarkan sebagai berikut:

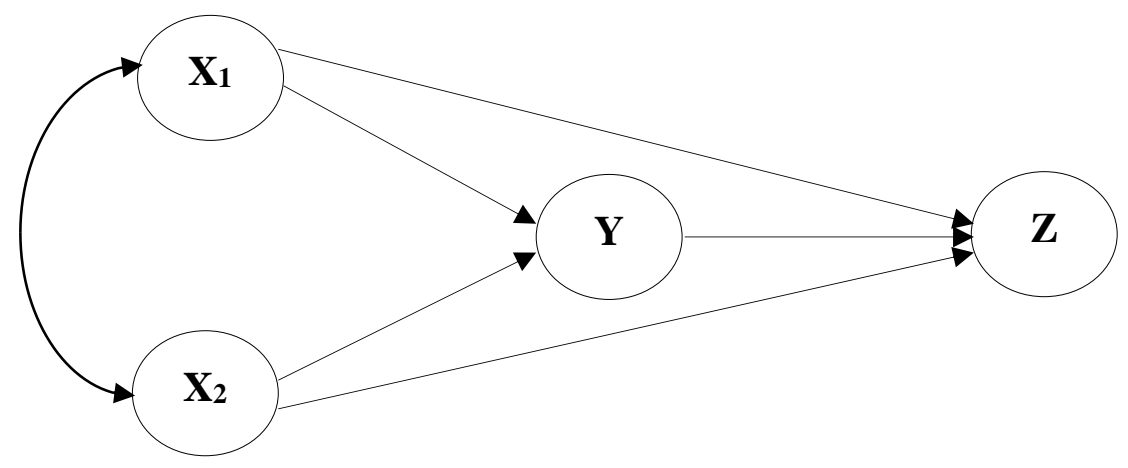

Gambar 2. Kerangka Berpikir

Keterangan:

$\mathrm{X}_{1}$ : Lingkungan Keluarga

$\mathrm{X}_{2}$ : Efikasi Diri

$\mathrm{Y}$ : Motivasi Berwirausaha

$\mathrm{Z}$ : Intensi Berwirausaha

\section{F. Hipotesis}

Berdasarkan rumusan masalah dan beberapa asumsi yang telah dikemukakan terdahulu dapat dirumuskan hipotesis yang merupakan dugaan sementara. Penulis merumuskan hipotesis berkenaan dengan masalah yang diteliti sebagai berikut:

1. Ho: Tidak terdapat pengaruh lingkungan keluarga terhadap motivasi berwirausaha.

Ha: Terdapat pengaruh lingkungan keluarga terhadap motivasi berwirausaha.

2. Ho: Tidak terdapat pengaruh efikasi diri terhadap motivasi berwirausaha.

Ha: Terdapat pengaruh efikasi diri terhadap motivasi berwirausaha.

3. Ho: Tidak terdapat pengaruh lingkungan keluarga terhadap intensi berwirausaha.

Ha: Terdapat pengaruh lingkungan keluarga terhadap intensi berwirausaha.

4. Ho: Tidak terdapat pengaruh efikasi diri terhadap intensi berwirausaha.

Ha: Terdapat pengaruh efikasi diri terhadap intensi berwirausaha.

5. Ho: Tidak terdapat pengaruh motivasi berwirausaha terhadap intensi berwirausaha.

Ha: Terdapat pengaruh motivasi berwirausaha terhadap intensi berwirausaha.

6. Ho: Tidak terdapat pengaruh lingkungan keluarga terhadap intensi berwirausaha melalui motivasi berwirausaha.

Ha: Terdapat pengaruh lingkungan keluarga terhadap intensi berwirausaha melalui motivasi berwirausaha. 
7. Ho: Tidak terdapat pengaruh efikasi diri terhadap intensi berwirausaha melalui motivasi berwirausaha.

Ha: Terdapat pengaruh efikasi diri terhadap intensi berwirausaha melalui motivasi berwirausaha.

\section{METODE PENELITIAN}

\section{Rancangan Penelitian}

Penelitian ini termasuk dalam golongan asosiatif kausalitas. Digolongkan asosiatif karena penelitian ini untuk mengetahui ada atau tidaknya hubungan antar variable yang di teliti. Dikategorikan kausalitas, karena penelitian ini bertujuan untuk mengetahui apakah variablevariabel yang di amati mempunyai hubungan sebab akibat tertentu seperti yang diduga secara teoritis.

Berdasarkan tujuan penelitian, penelitian ini dikategorikan sebagai penelitian penjelas (eksplanatory research) yaitu suatu penelitian yang menjelaskan masing-masing variable melalui pengujian hipotesis. Teknis analisis yang digunakan dalam penelitian ini adalah analisis jalur (path analisys).

\section{Variabel Penelitian}

1. Variabel Bebas

Adapun variable independent dalam penelitian ini adalah: 1) lingkungan keluarga $\left(\mathrm{X}_{1}\right)$; dan 2) efikasi diri $\left(\mathrm{X}_{2}\right)$.

2. Variabel Intervening (Mediasi)

Adapun variable intevening pada penelitian ini adalah motivasi berwirausaha (Y).

3. Variabel Terikat

Adapun variable dependent pada penelitian ini adalah intensi berwirausaha $(Z)$.

\section{Tempat dan Waktu Penelitian}

Penelitian ini dilaksanakan pada Fakultas Keguruan dan Ilmu Pendidikan, Universitas Jambi yang dilaksanakan pada Januari 2019 sampai dengan Desember 2019.

\section{Populasi dan Sampel.}

1. Populasi

Adapun populasi dalam penelitian ini adalah mahasiswa Fakultas Keguruan dan Ilmu Pendidikan (FKIP) Universitas Jambi yang telah mengikuti mata kuliah kewirausahaan tahun tahun 2016 dan 2017 yang terdiri dari enam kelas dengan jumlah 236 mahasiswa.

2. Sampel

Jumlah sampel dalam penelitian adalah 236 mahasiswa.

\section{Instrumen Penelitian}

Instrument penelitian digunakan untuk mengukur nilai variable yang di teliti. Jumlah instrument penelitian tergantung pada jumlah variable tersebut yang ditetapkan untuk di teliti. Instrument dalam penelitian ini adalah angket dan dokumentasi. Skala Likert digunakan untuk mengukur sikap, pendapat orang atau sekelompok tentang kejadian atau gejala sosial (Riduwan dan Kuncoro, 2013).

\section{Teknik Pengumpulan Data}

Dalam penelitian ini teknik pengumpulan data yang digunakan adalah sebagai berikut:

a. Kuesioner

b. Studi dokumentasi

\section{Transformasi Data}


Variabel-variabel penelitian ini diukur dengan menggunakan skala Likert Summated Rating's (LSR) untuk setiap pilihan jawaban diberi skor dan skor yang diperoleh mempunyai tingkat pengukuran ordinal.

\section{Uji Instrumen Penelitian}

Uji Instumen yang di gunakan adalah Uji Validitas dan Uji Reliabilitas

\section{Uji Prasyarat}

Uji prasyarat yang digunakan adalah Uji Normalitas, Uji Multikolinearitas, dan Uji Heterokedastisitas

\section{Analisis Deskriptif}

Langkah awal untuk menganalisa data dalam penelitian ini yaitu:

1. Menghitung skor-skor dari setiap butir soal kemudian skor-skor tersebut dijumlahkan untuk mendapatkan skor total.

2. Menentukan range $=$ skor tertinggi - skor terendah.

3. Untuk menentukan banyaknya kelas dengan melihat banyak kategori yang digunakan dalam penelitian ini ada 5 kategori, yaitu sangat baik, baik, cukup baik, buruk, dan sangat buruk.

4. Menentukan panjang interval dengan rumus:

$$
\text { Panjang Interval }=\frac{\text { Range }}{\text { Jumlah Kelas }}
$$

5. Kemudian di konversikan kedalam tabel kriteria penafsiran skor

\section{Analisis Jalur (Path Analysis)}

Mengingat penelitian ini menggunakan analisis jalur (Path Analysis) maka terdapat beberapa asumsi dasar untuk memenuhi kaedah Trimming Theory (Teori Trimming), diantaranya:

1. Hubungan antar variabel harus bersifat linear.

2. Model penelitian memiliki hubungan kausalitas dengan panah satu arah/one-way causal flow (recursive model). Pengujian dilakukan secara parsial dengan OLS (analisis regresi).

3. Varriabel endogen minimal dalam skala interval.

4. Instrument penelitian harus reliabel dan valid (variabel diukur tanpa kesalahan).

5. Model penelitian sesuai dengan teori dan konsep.

\section{Uji Hipotesis}

Uji hipotesis yang digunakan adalah Koefisien Determinasi $\left(R^{2}\right)$, Uji Parsial (Uji t), dan Uji Intervening

\section{Rancangan Uji Hipotesis}

1. Lingkungan keluarga berpengaruh terhadap motivasi berwirausaha.

Ho : $\mathrm{Zx}_{1}=0$

$\mathrm{Ha}: \mathrm{Zx}_{1} \neq 0$

2. Efikasi diri berpengaruh terhadap motivasi berwirausaha.
Ho : $\mathrm{Zx}_{2}=0$
$\mathrm{Ha}: \mathrm{Zx}_{2} \neq 0$

3. Lingkungan keluarga berpengaruh terhadap intensi berwirausaha.

Ho $: \mathrm{Zx}_{1}=0$
$\mathrm{Ha}: \mathrm{Zx}_{1} \neq 0$

4. Efikasi diri berpengaruh terhadap intensi berwirausaha.

Ho : $\mathrm{Zx}_{2}=0$

$\mathrm{Ha}: \mathrm{Zx}_{2} \neq 0$ 
5. Motivasi berwirausaha berpengaruh terhadap intensi berwirausaha.

Ho : $\mathrm{Zx}_{3}=0$

$\mathrm{Ha}: \mathrm{Zx}_{3} \neq 0$

6. Lingkungan keluarga berpengaruh terhadap intensi berwirausaha melalui motivasi berwirausaha.

Ho : $\mathrm{Zx}_{1} \Omega \mathrm{y}=0$

$\mathrm{Ha}: \mathrm{Zx}_{1} \Omega \mathrm{y} \neq 0$

7. Efikasi diri berpengaruh terhadap intensi berwirausaha melalui motivasi berwirausaha.

Ho : $\mathrm{Zx}_{2} \Omega \mathrm{y}=0$

$\mathrm{Ha}: \mathrm{Zx}_{2} \Omega \mathrm{y} \neq 0$

\section{HASIL DAN PEMBAHASAN}

\section{Hasil Penelitian}

Pada bagian berikut ini penulis akan mendeskripsikan variabel yang diteliti satu persatu sebagai berikut.

\section{Deskriptif Variabel Lingkungan Keluarga $\left(\mathrm{X}_{1}\right)$}

Berdasarkan data hasil penelitian, diperoleh skor terendah 51 dan skor tertinggi 88. Hasil perhitungan distribusi skor tersebut menghasilkan skor rata-rata sebesar 68,9 dan simpangan baku sebesar 7,73.

\section{Deskriptif Variabel Efikasi Diri ( $\left.\mathbf{X}_{2}\right)$}

Berdasarkan data hasil penelitian, diperoleh skor terendah 47 dan skor tertinggi 77 . Hasil perhitungan distribusi skor tersebut menghasilkan skor rata-rata sebesar 62,119 dan simpangan baku sebesar 6,207.

\section{Deskriptif Variabel Motivasi Berwirausaha (Y)}

Berdasarkan data hasil penelitian, diperoleh skor terendah 48 dan skor tertinggi 102. Hasil perhitungan distribusi skor tersebut menghasilkan skor rata-rata sebesar 77,53 dan simpangan baku sebesar 9,377.

\section{Deskriptif Variabel Intensi Berwirausaha $(Z)$}

Berdasarkan data hasil penelitian, diperoleh skor terendah 46 dan skor tertinggi 85. Hasil perhitungan distribusi skor tersebut menghasilkan skor rata-rata sebesar 66,242 dan simpangan baku sebesar 7,617

\section{Hasil Uji Prasyarat}

\section{Uji Normalitas}

Tabel 1. Hasil Uji Normalitas Secara Statistik

One-Sample Kolmogorov-Smirnov Test

\begin{tabular}{|ll|r|r|r|r|}
\hline & & X1_LingKel & X2_EfikasiD & Y_MotBer & Z_IntenBer \\
\hline N & & 236 & 236 & 236 & 236 \\
Normal Parameters ${ }^{\mathrm{a}, \mathrm{b}}$ & Mean & 68,890 & 62,119 & 77,530 & 66,242 \\
& Std. Deviation & 7,7314 & 6,2073 & 9,3774 & 7,6167 \\
& Absolute &, 048 &, 077 &, 072 &, 068 \\
Most Extreme Differences & Positive &, 042 &, 071 &, 059 &, 048 \\
& Negative &,- 048 &,- 077 &,- 072 &,- 068 \\
Kolmogorov-Smirnov Z & &, 735 & 1,185 & 1,101 & 1,049 \\
Asymp. Sig. (2-tailed) & &, 653 &, 121 &, 177 &, 222 \\
\hline
\end{tabular}

a. Test distribution is Normal.

b. Calculated from data.

Maka dapat disimpulkan keempat variable tersebut ini berdistribusi normal.

\section{Uji Multikolinearitas}


Tabel 2. Hasil Uji Multikolinearitas

Sumber: Output SPSS 21.0

\begin{tabular}{|rl|r|r|}
\hline \multirow{2}{*}{ Model } & \multicolumn{2}{|c|}{ Collinearity Statistics } \\
\cline { 3 - 4 } & & Tolerance & \multicolumn{1}{c|}{ VIF } \\
\hline \multirow{4}{*}{1} & (Constant) & & \\
& X1_LingKel &, 269 & 3,720 \\
& X2_EfikasiD &, 495 & 2,018 \\
& Y_MotBer &, 309 & 3,240 \\
\hline
\end{tabular}

Dapat disimpulkan bahwa tidak terjadi multikolinearitas antar variabel Independent dalam model regresi.

\section{Uji Heterokedastisitas}

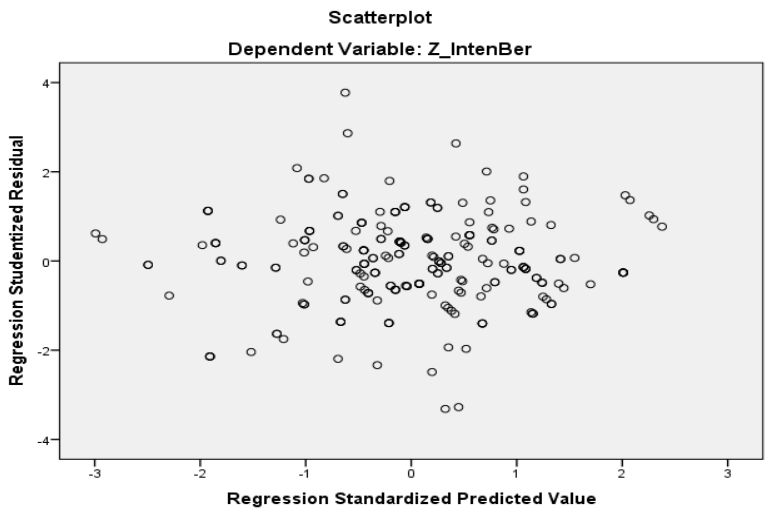

Gambar 3. Scatterplot Heterokedastisitas

Dari Gambar 4.2 scatterplots terlihat bahwa titik-titik menyebar secara acak serta tersebar baik diatas maupun dibawah angka 0 pada sumbu Y. hal ini dapat disimpulkan bahwa tidak terjadi heterokedastisitas pada model, sehingga model layak dipakai untuk memprediksi penggunaan jasa akomodasi berdasarkan masukan variabel independent.

\section{Hasil Analisis Jalur (Path Analisys)}

Berikut ini merupakan hasil analisis jalur dalam penelitian ini dirangkum pada tabel berikut.

\begin{tabular}{llcccc} 
Model & \multicolumn{2}{c}{ Tabel 3. Output Analisis Jalur } \\
Unstandardized & $\begin{array}{c}\text { Standardized } \\
\text { Coefficients }\end{array}$ & t & Sig. \\
& Coefficients & & \\
& B & Std. Error & Beta & & \\
\hline $\mathrm{X}_{1}-\mathrm{Y}$ & 1,002 & 0,045 & 0,826 & 22,450 & 0,000 \\
\hline $\mathrm{X}_{2}-\mathrm{Y}$ & 0,974 & 0,075 & 0,645 & 12,899 & 0,000 \\
\hline $\mathrm{X}_{1}-\mathrm{Z}$ & 0,811 & 0,037 & 0,823 & 22,157 & 0,000 \\
\hline $\mathrm{X}_{2}-\mathrm{Z}$ & 0,810 & 0,060 & 0,660 & 13,436 & 0,000 \\
\hline $\mathrm{Y}-\mathrm{Z}$ & 0,707 & 0,026 & 0,871 & 27,107 & 0,000
\end{tabular}

Sumber: Output SPSS 21.0 for windows.

\section{Pengujian Hipotesis}

Pengaruh Lingkungan Keluarga Terhadap Motivasi Berwirausaha. 
Tabel 4. Hasil Perhitungan Uji Hipotesis 1 Coefficients $^{\text {a }}$

\begin{tabular}{|rl|r|r|r|r|r|}
\hline \multicolumn{2}{|l|}{ Model } & \multicolumn{2}{|c|}{ Unstandardized Coefficients } & \multicolumn{1}{|c|}{$\begin{array}{c}\text { Standardized } \\
\text { Coefficients }\end{array}$} & \multirow{2}{*}{ Sig. } \\
\cline { 3 - 5 } & & \multicolumn{1}{|c|}{ B } & Std. Error & Beta & & \\
\hline \multirow{2}{*}{1} & (Constant) & 8,480 & 3,095 & & 2,740 &, 007 \\
& X1_LingKel & 1,002 &, 045 &, 826 & 22,450 &, 000 \\
\hline
\end{tabular}

a. Dependent Variable: Y_MotBer

Sumber: Output SPSS 21.0 for windows.

Sesuai hasil perhitungan di atas dapat disimpulkan bahwa hipotesis 1 yang diajukan dapat diterima.

\section{Pengaruh Efikasi Diri Terhadap Motivasi Berwirausaha}

Tabel 5. Hasil Perhitungan Uji Hipotesis 2

Coefficients $^{\mathrm{a}}$

\begin{tabular}{|rl|r|r|r|r|r|}
\hline \multirow{2}{*}{ Model } & \multicolumn{2}{|c|}{ Unstandardized Coefficients } & \multicolumn{1}{|c|}{$\begin{array}{c}\text { Standardized } \\
\text { Coefficients }\end{array}$} & \multirow{2}{*}{ Sig. } \\
\cline { 3 - 5 } & & \multicolumn{1}{|c|}{ B } & Std. Error & Beta & & \\
\hline \multirow{2}{*}{1} & (Constant) & 17,034 & 4,713 & & 3,614 &, 000 \\
& X2_EfikasiD &, 974 &, 075 &, 645 & 12,899 &, 000 \\
\hline
\end{tabular}

a. Dependent Variable: Y_MotBer Sumber: Output SPSS 21.0 for windows.

Sesuai hasil perhitungan di atas dapat disimpulkan bahwa hipotesis 2 yang diajukan dapat diterima.

\section{Pengaruh Lingkungan Keluarga Terhadap Intensi Berwirausaha.}

Tabel 6. Hasil Perhitungan Uji Hipotesis 3

Coefficients $^{\mathrm{a}}$

\begin{tabular}{|rl|r|r|r|r|r|}
\hline \multicolumn{2}{|l|}{ Model } & \multicolumn{2}{|c|}{ Unstandardized Coefficients } & \multicolumn{1}{|c|}{$\begin{array}{c}\text { Standardized } \\
\text { Coefficients }\end{array}$} & \multirow{2}{*}{ Sig. } \\
\cline { 3 - 5 } & \multicolumn{1}{|c|}{ B } & Std. Error & Beta & & \\
\hline \multirow{2}{*}{1} & (Constant) & 10,391 & 2,536 & & 4,097 &, 000 \\
& X1_LingKel &, 811 &, 037 &, 823 & 22,157 &, 000 \\
\hline
\end{tabular}

a. Dependent Variable: Z_IntenBer

Sumber: Output SPSS 21.0 for windows.

Sesuai hasil perhitungan di atas dapat disimpulkan bahwa hipotesis 3 yang diajukan dapat diterima.

\section{Pengaruh Efikasi Diri Terhadap Intensi Berwirausaha.}

Tabel 7. Hasil Perhitungan Uji Hipotesis 4

$$
\text { Coefficients }^{\mathrm{a}}
$$

\begin{tabular}{|rl|r|r|r|r|r|}
\hline \multicolumn{2}{|l|}{ Model } & \multicolumn{2}{|c|}{ Unstandardized Coefficients } & \multicolumn{1}{|c|}{$\begin{array}{c}\text { Standardized } \\
\text { Coefficients }\end{array}$} & \multirow{2}{*}{ Sig. } \\
\cline { 3 - 5 } & & \multicolumn{1}{|c|}{ B } & Std. Error & Beta & & \\
\hline \multirow{2}{*}{1} & (Constant) & 15,940 & 3,762 & & 4,237 &, 000 \\
& X2_EfikasiD &, 810 &, 060 &, 660 & 13,436 &, 000 \\
\hline
\end{tabular}

a. Dependent Variable: Z_IntenBer

Sumber: Output SPSS 21.0 for windows

Sesuai hasil perhitungan di atas dapat disimpulkan bahwa hipotesis 4 yang diajukan dapat diterima. 


\section{Pengaruh Motivasi Berwirausaha Terhadap Intensi Berwirausaha}

Tabel 8. Hasil Perhitungan Uji Hipotesis 5

Coefficients $^{\mathrm{a}}$

\begin{tabular}{|c|c|c|c|c|c|c|}
\hline \multirow{2}{*}{\multicolumn{2}{|c|}{ Model }} & \multicolumn{2}{|c|}{ Unstandardized Coefficients } & \multirow{2}{*}{$\begin{array}{c}\begin{array}{c}\text { Standardized } \\
\text { Coefficients }\end{array} \\
\text { Beta }\end{array}$} & \multirow[t]{2}{*}{$\mathrm{t}$} & \multirow[t]{2}{*}{ Sig. } \\
\hline & & $\mathrm{B}$ & Std. Error & & & \\
\hline \multirow{2}{*}{1} & (Constant) & 11,399 & 2,038 & & 5,593 &, 000 \\
\hline & Y_MotBer & ,707 &, 026 & ,871 & 27,107 &, 000 \\
\hline
\end{tabular}

a. Dependent Variable: Z_IntenBer

Sumber: Output SPSS 21.0 for windows

Sesuai hasil perhitungan di atas dapat disimpulkan bahwa hipotesis 5 yang diajukan dapat diterima.

\section{Pengaruh Lingkungan Keluarga Melalui Motivasi Berwirausaha Terhadap Minat Berwirausaha.}

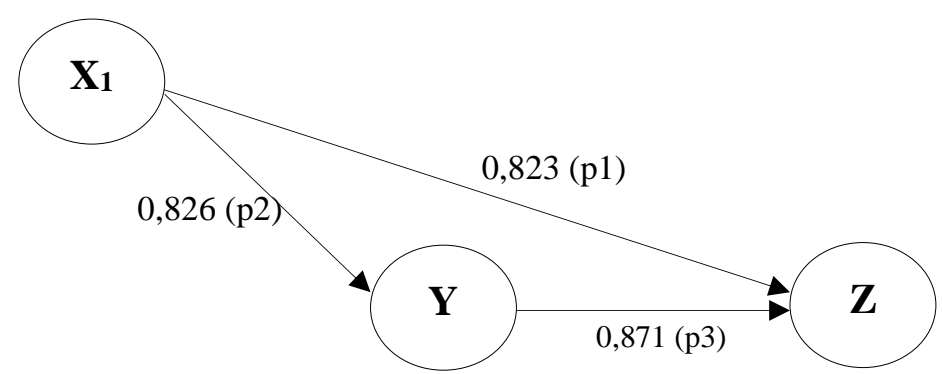

Gambar 4. Model Analisis Jalur Lingkungan Keluarga Melalui Motivasi Berwirausaha Terhadap Intensi Berwirausaha.

Hasil analisis jalur menunjukan bahwa lingkungan keluarga dapat berpengaruh langsung terhadap intensi berwirausaha dan dapat juga berpengaruh tidak langsung yaitu dari lingkungan keluarga ke motivasi berwirausaha (sebagai variabel intervening) lalu ke intensi berwirausaha.

Pengaruh Efikasi Diri Melalui Motivasi Berwirausaha Terhadap Minat Berwirausaha.

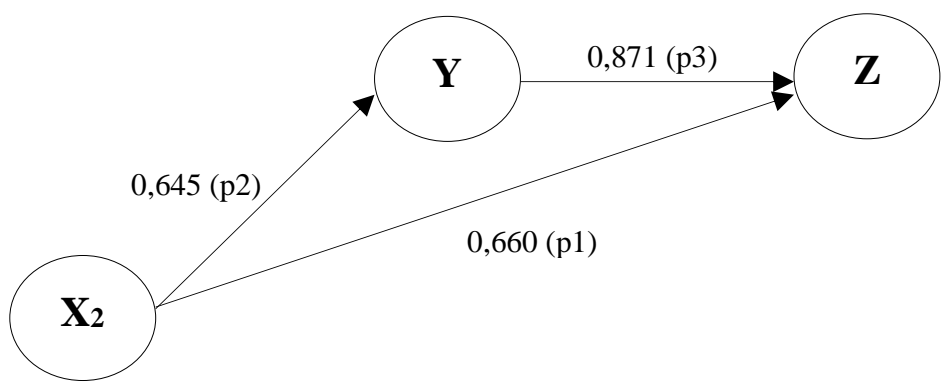

Gambar 5. Model Analisis Jalur Efikasi Diri Melalui Motivasi Berwirausaha Terhadap Intensi Berwirausaha.

Hasil analisis jalur menunjukan bahwa efikasi dapat berpengaruh langsung terhadap intensi berwirausaha dan dapat juga berpengaruh tidak langsung yaitu dari efikasi diri ke motivasi berwirausaha (sebagai variabel intervening) lalu ke intensi berwirausaha.

\section{Pembahasan}

\section{Pengaruh Lingkungan Keluarga Terhadap Motivasi Berwirausaha}

Berdasarkan pengujian hipotesis yang dilakukan, lingkungan keluarga berpengaruh positif signifikan terhadap motivasi berwirausaha.

Pengaruh Efikasi Diri Terhadap Motivasi Berwirausaha 
Dari pengujian hipotesis yang dilakukan diketahui bahwa efikasi diri berpengaruh positif signifikan terhadap motivasi berwirausaha.

\section{Pengaruh Lingkungan Keluarga Terhadap Intensi Berwirausaha}

Berdasarkan pengujian hipotesis yang dilakukan, lingkungan keluarga berpengaruh positif signifikan terhadap intensi berwirausaha.

\section{Pengaruh Efikasi Diri Terhadap Intensi Berwirausaha}

Dari pengujian hipotesis yang dilakukan diketahui bahwa efikasi diri berpengaruh positif signifikan terhadap intensi berwirausaha.

\section{Pengaruh Motivasi Berwirausaha Terhadap Intensi Berwirausaha}

Dari pengujian hipotesis yang dilakukan diketahui bahwa motivasi berwirausaha berpengaruh positif signifikan terhadap intensi berwirausaha.

Pengaruh Lingkungan Keluarga Melalui Motivasi Berwirausaha Terhadap Intensi Berwirausaha.

Dari pengujian analisa uji intervening lingkungan keluarga terhadap intensi berwirausaha melalui motivasi berwirausaha diperoleh hasil bahwasanya lingkungan keluarga dapat berpengaruh langsung terhadap intensi berwirausaha dan dapat juga berpengaruh tidak langsung yaitu dari lingkungan keluarga ke motivasi berwirausaha (sebagai variabel intervening) lalu ke intensi berwirausaha. Besarnya pengaruh langsung adalah 0,823, sedangkan besarnya pengaruh tidak langsung harus dihitung dengan mengalikan koefisien tidak langsungnya sehingga diperoleh nilai 0,719446. Dan total pengaruh lingkungan keluarga ke intensi berwirausaha sebesar 1,542446.

\section{Pengaruh Efikasi Diri Melalui Motivasi Berwirausaha Terhadap Intensi Berwirausaha.}

Dari pengujian analisa uji intervening efeikasi diri terhadap minat berwirausaha melalui motivasi berwirausaha diperoleh hasil bahwasanya efikasi diri dapat berpengaruh langsung terhadap intensi berwirausaha dan dapat juga berpengaruh tidak langsung yaitu dari efikasi diri ke motivasi berwirausaha (sebagai variabel intervening) lalu ke intensi berwirausaha. Besarnya pengaruh langsung adalah 0,669, sedangkan besarnya pengaruh tidak langsung harus dihitung dengan mengalikan koefisien tidak langsungnya sehingga diperoleh nilai 0,561795. Dan total pengaruh efikasi diri ke intensi berwirausaha sebesar 0,1,230795.

\section{KESIMPULAN DAN SARAN}

\section{Kesimpulan}

Berdasarkan hasil penelitian yang diperoleh secara keseluruhan, maka dapat disimpulkan sebagai berikut:

1. Berdasarkan hasil perhitungan dan analisis, Maka dapat disimpulkan bahwa lingkungan keluarga berpengaruh signifikan terhadap motivasi berwirausaha mahasiswa.

2. Berdasarkan hasil perhitungan dan analisis, maka dapat disimpulkan bahwa efikasi diri berpengaruh signifikan terhadap motivasi berwirausaha mahasiswa.

3. Berdasarkan hasil perhitungan dan analisis, maka dapat disimpulkan bahwa lingkungan keluarga berpengaruh signifikan terhadap intensi berwirausaha mahasiswa.

4. Berdasarkan hasil perhitungan dan analisis, maka dapat disimpulkan bahwa efikasi diri berpengaruh signifikan terhadap intensi berwirausaha mahasiswa.

5. Berdasarkan hasil perhitungan dan analisis, maka dapat disimpulkan bahwa motivasi berwirausaha berpengaruh signifikan terhadap intensi berwirausaha mahasiswa.

6. Berdasarkan hasil perhitungan dan analisis, maka dapat disimpulkan bahwa koefisien mediasi 0,719446 signifikan yang berarti bahwa motivasi berwirausaha mampu memediasi lingkungan keluarga terhadap intensi berwirausaha. 
7. Berdasarkan hasil perhitungan dan analisis, maka dapat disimpulkan bahwa koefisien mediasi 0,561795 signifikan yang berarti bahwa motivasi berwirausaha mampu memediasi efikasi diri terhadap intensi berwirausaha.

\section{Saran}

a. Bagi Orang Tua dan Keluarga Umumnya

Orang tua hendaknya melakukan komunikasi aktif kepada anaknya untuk memberikan gambaran-gambaran peluang yang dapat diraih anak sehingga diharapkan anak dapat berwirausaha dimasa mendatang dengan bekal yang lebih memadai.

b. Bagi Fakultas Keguruan dan Ilmu Pendidikan

Agar dapat mendirikan suatu unit usaha yang dikelola oleh civitas academika Fakultas Keguruan dan Ilmu Pendidikan..

c. Bagi Mahasiswa

Hendaknya melatih mengontrol diri dan keterampilannya agar siap dalam berwirausaha setelah lulus kuliah dengan menggunakan keterampilan yang dimiliki untuk berwirausaha.

d. Bagi Peneliti Selanjutnya

Penelitian selanjutnya diharapkan dapat mengembangkan ini dengan meneliti lebih lanjut ketingkat action untuk berwirausaha

\section{DAFTAR RUJUKAN}

Ajzen, I \& Fishbein, M. 2005. Personality and Behavior $\left(2^{\text {nd }} E d\right)$. London: Open University Press.

Alma, B. 2018. Kewirausahaan: Untuk Mahasiswa dan Umum. Bandung: Alpabeta.

Bandura, A. 2006. Article of guide for Contructing Self Efficacy Scales. by Information Age Publishing.

Farida, I., \& Mahmud. 2015. Pengaruh theory planned of behavior terhadap intensi berwirausaha mahasiswa. Forum Bisnis Dan Kewirausahaan Jurnal Ilmiah STIE $M D P, 5,39$.

Kusuma, M.W.A., dan Warmika, I.G.K. 2016. Analisis Faktor-Faktor Yang Mempengaruhi Intensi Berwirausaha Pada Mahasiswa S1 FEB UNUD. E-Jurnal Manajemen Unud, Vol. 5, No. 1.

Latif, A. 2011. Pendidikan Berbasis Nilai Kemasyarakatan. Bandung: PT. Refika Aditama.

Luthans, Fred. 2006. Perilaku Organisasi. Yogyakarta: Andi.

Ormrod, Jeanne Ellis. 2008. Psikologi Pendidikan (membantu siswa tumbuh dan berkembang jilid 2). Jakarta. Erlangga.

Puspitaningsih, F. 2014. Pengaruh Efikasi Diri dan Pengetahuan Kewirausahaan Terhadap Minat Berwirausaha Melalui Motivasi. Jurnal Ekonomi Pendidikan dan Kewirausahaan, Vol. 2, No. 2.

Riduwan dan Kuncoro, E.K. 2013. Cara Menggunakan dan Memaknai Path Analysis. Alfabeta: Bandung.

Robbins, S.P. \& Judge, T. 2015. Organizational Behavior. Pearson: Education Limited.

Slameto. 2010. Belajar dan Faktor-Faktor yang Mempengaruhinya. Jakarta: Rineka Cipta.

Sugiyono. 2012. Statistika Untuk Penelitian. Bandung: Alfabeta.

Suryana. 2014. Kewirausahaan Kiat dan Proses Menuju Sukses Edisi Empat. Jakarta: Salemba Empat. 
Suryana, Y. \& Bayu, K. 2014. Kewirausahaan: Pendekatan Karakteristik Wirausahawan Sukses. Jakarta: Kencana.

Wibowo. 2011. Manajemen Kinerja. Jakarta: Raja Grafindo Persada.

Wibowo. 2013. Perilaku Dalam Organisasi. Jakarta: Raja Grafindo Persada.

Yalcin, S. \& Kapu, H. 2008. Entrepreneurial dimensions in transitional economies: A review of relevant literature and the case of Kyrgyzstan. Journal of Developmental Entrepreneurship, 13(2), 185-203.

Zubaedi. 2011. Desain Pendidikan Karakter: Konsepsi dan Aplikasinya dalam Lembaga Pendidikan. Jakarta: Kencana Prenada Media Group. 